Jianfu Chen, Yuwen Li, Jan Michiel Otto eds, The Implementation of Law in the People's Republic of China

The Hague, London, New York, Kluwer Law International, 2002, 370 pp.

Leïla Choukroune

OpenEdition

Journals

Electronic version

URL: http://journals.openedition.org/chinaperspectives/653

DOI: $10.4000 /$ chinaperspectives.653

ISSN: 1996-4617

Publisher

Centre d'étude français sur la Chine contemporaine

Printed version

Date of publication: 1 October 2003

ISSN: 2070-3449

Electronic reference

Leilla Choukroune, « Jianfu Chen, Yuwen Li, Jan Michiel Otto eds, The Implementation of Law in the People's Republic of China », China Perspectives [Online], 49 | september-october 2003, Online since 17 January 2007, connection on 22 September 2020. URL : http://journals.openedition.org/

chinaperspectives/653; DOI : https://doi.org/10.4000/chinaperspectives.653

This text was automatically generated on 22 September 2020.

(c) All rights reserved 


\title{
Jianfu Chen, Yuwen Li, Jan Michiel Otto eds, The Implementation of Law in the People's Republic of China
}

The Hague, London, New York, Kluwer Law International, 2002, 370 pp.

\author{
Leïla Choukroune
}

\section{EDITOR'S NOTE}

Translated from the French original by Nick Oates

1 To have a modernised, though certainly less than perfect legislative apparatus is one thing. To apply it uniformly, fairly and with complete independence across the entirety of a vast territory is quite another. By opening this collective work with a preface dedicated to the impact that the accession of China to the World Trade Organisation (WTO) has had on Chinese legislative activity, the authors of The Implementation of Law in the People's Republic of China offer a striking image of the inherent contradictions in the judicial system of this country. In the space of eighteen months, nearly 2,500 texts of acts and regulations of a commercial nature have been amended in order to bring them into line with WTO law, while several hundred new texts have been or are on the point of being adopted. A major suite of norms has thus been born, comprising texts as essential as the new catalogue on the orientation of foreign investments, the new antidumping regulations and the law on trademarks. This unprecedented explosion of legislation is, however, only one step in the process of bringing Chinese law into conformity with international standards, for it no way guarantees the legal security of business and more generally what Jan Michiel Otto describes as "real legal certainty", a concept that covers "the predictability of applicable rules in a particular context as 
much as the judicial interpretation and application of those rules by the judicial power and the other authorities entrusted with the implementation of the law"1.

2 The Implementation of Law in the People's Republic of China does not deal specifically with the integration of China into international commerce, but with the difficulties linked to the application of the law (zhixing nan) in areas as varied as the fight against corruption (Ye Feng), the legal professions (Randall Peerenboom) and environmental law (Benjamin van Rooij). The work underlines the progress made and the resistance encountered in the transformation from a "law of books" into a "law in action" in the context of this China that is currently in the middle of the reform process. Without falling into the trap of juridicism, the authors illuminate the different facets of a complex problem that is all too often neglected by judicial doctrine. After clearly demonstrating that the "disorganised" reforms of the Chinese judicial system-including those of 1999-are tending to create a certain professionalisation without, for all that, succeeding in damming an endemic corruption, Yuwen Li insists on the necessity of making this system transparent, fair and impartial through fundamental changes that would aim in particular at minimising the influence that the Party exerts on the nomination of judges or the proceedings of a case.

3 The argument in this contribution is continued in that of Jianfu Chen which focuses on the impossibility of executing civil judgements and the disrepute into which these decisions "without value" (falü baitiao) have fallen among the Chinese population. Starting from the established fact that there is no separation of powers, Cai Dingjian reveals to what extent the powers of the National People's Assembly and of its permanent committee have been expanded over the past ten years until a unique but no less dangerous situation has emerged: a parliament - not exactly democratic and screened from any checks and balances- endowed with powers to interpret and control the application of laws and legal decisions!

4 The demonstration closes with four very different case studies. In a rambling chapter that mixes questions of public and of private law and which would have merited being developed and brought very clearly up to date, Shaping shao takes on the task of defining the position of international law in domestic Chinese law. The author does not, however, fully answer the thorny question of the harmonisation of judicial orders. It is also deeply regrettable that she has not been able to get away from an unceasingly wooden language that portrays China as a leading player in the maintaining of "international peace" and in "the promotion and the development of international law" since "ancient times", though it is well known that both achievements and doctrinal studies in law are thin on the ground in China, if not non-existent. Shaping Shao further loses her way when she asserts, for example, that as China is a party to the United Nations Convention of December 3rd 1984 against torture and other cruel, inhuman or degrading treatment, it only has to transpose into domestic law the provisions of this convention. Do not the multiple reports of international human rights organisations bear witness to this perfect transposition of international standards? It remains to be hoped that the recent publication of the Chinese Journal of International Law will enlighten us on this highly complex of problems².

Perhaps not exactly neutral either, but well argued, the work of Albert H.Y. Chen tackles the transformations of Hong Kong's legal system. The last two case studies are certainly the most original. $\mathrm{Hu}$ Yunteng paints an extraordinary portrait of the application of capital punishment, to conclude in favour of its extensive application, 
subject, at the local level, to extrajudicial criteria. Finally, Perry Keller is interested in the regulatory environment in which the Chinese media is evolving, torn as it is between the imperatives of opening up to international competition and complying with the directives emanating from the Party.

Well-documented and provided with a complete critical apparatus, the work is also enriched by interesting appendices. Jianfu Chen draws a synthetic table of the principal actors in Chinese judicial life (legal institutions and professionals) while underlining with precision the unfinished and evolutionary character of the reforms that have engendered their creation. And Benjamin van Rooij recalls in pertinent fashion the fundamental principles of the administrative organisation by highlighting the key role of the system of nomenklatura under the control of the Party-state. Finally, the last annex offers an eclectic selection of provisions each as ambiguous as the next, but which are supposed to form a body of reference when it comes to application of the law.

7 Continuing the work of systematisation begun by the publication of Law Making in the People's Republic of China, the greatest merit of this work, which is certainly uneven but the reading of which we can only recommend, is that it provides an unequalled analysis of one of the principle obstacles not just to the judicial but also to the political reforms of the last twenty-five years ${ }^{3}$. There are many who, in the Chinese academic world, denounce China's inability to observe its own legislation -as rudimentary as it is. The recent petition addressed to the National People's Congress by three young university faculty members in Peking, with the intention of demanding the application of the rights guaranteed to the individual by the constitution, starting with the protection of migrant workers, illustrates perfectly the dichotomy that exists in China between word and action ${ }^{4}$. In the image of the case of Zhang Jianzhong, the prominent defence lawyer convicted on February 25th 2003 for complicity in the fabrication of evidence in a corruption case, the reality of the Chinese judicial process cruelly reminds us that we are dealing with an application of the law that is nothing less than selective ${ }^{5}$. If the right to a fair trial exists, even if only partially, in the texts, its application often only gives rise to a simulacrum of justice. The rule of law that Jianfu Chen wishes will not see the light of day without a political will that not simply relies on judicial pragmatism, but that seeks to go beyond it in order to install a regime in which a system of counterbalances guarantees the independence and the impartiality of justice in front of those in government. It thus remains for China to conduct one last politico-legal battle ${ }^{6}$.

\section{NOTES}

1. See Chapter II, "Toward an analytical framework: real legal certainty and its explanatory factors", pp. 23-34.

2. Chinese Journal of International Law, http://www.chinesejil.or

3. See our report in China Perspectives, No. 38, November-December 2001, pp. 80-82.

4. New York Times, June 2nd 2003. 
5. On the case of Zhang Jianzhong, see the report of the Congressional Executive Commission on China, http://www.cecc.gov, and Jerome A. Cohen, "The Plight of China's Criminal Defense Lawyers", Hong Kong Law Journal, Volume 33, Part 1, 2003, pp. 231-247.

6. Chen Jianfu, "Implementation of Law as a Politico-Legal Battle in China", China Perspectives, No. 43, September-October 2002, pp. 26-39. 